I am quite willing to extend the signification of Uniformitarian, in geology, to any action, however varied in intensity, from the most slow and steady to, at times, the most rapid or violent; as long as such catastrophes or paroxysms, as Mr. Scrope calls them, occur (like the striking of a clock) at regular or equidistant intervals of time, even if they do sccur "but once in a century, or even in a thousand years." Before, however, internal or volcanic action can be brought under such a heading, it must first be proved that their catastrophes or paroxysms do ocour at regular intervals; and until this is shown-more especially as the bulk of evidence at hand at present tends rather to the opposite conclusion-it does not appear unreasonable to continue to call these agencies Cataclysmic, as long as by the word Cataclysm in geology is understood some more than ordinarily violent event in the earth's physical history occurring at intervals altogether irregular and undeterminable.

\title{
David Forbes.
}

11, York Prace, Portman Seuare, London, W.

\section{A FACT RELATING TO THE CRAG PIT at THORPE, NEAR NORWICH.}

SrR,- - In my paper on the Norwich Crag and associated beds, read before the Geological Society last autumn, I mentioned a local feature which I had noticed some fifteen years since, and which I had not seen reproduced since that period, viz., the occurrence over the shelly sand (Norwich Crag), overlying the Chalk, of a thin bed of clay (which I suggested might be the Chillesford clay), succeeded by an ironstone conglomerate containing impressions of shells. On my visit there again last week, I found in a freshly cut part of the section at the west end of the pit the same features exhibited, but on a larger and better scale. A bed about 2 feet thick, at the lower part of the gravel capping the section, is cemented into a ferruginous conglomerate, which has been the means of preserving the casts and impressions of numerous shells. Under this is a bed of light grey clay, $1 \frac{1}{2}$ foot thick, and then 5 or 6 feet of white sand and fine gravel, with an abundance of the usual Norwich Crag shells in the lower part of it.

The impressions in the ferruginous conglomerate are very abundant and very well preserved. My visit was too short to make a proper collection of them, and as the bed may, as the former one was, be worked out before long, I would direct the attention of any geologists visiting the pit to the interest of making a good collection of these fossils, amongst which I noticed the following:-Pectunculus glycimeris (?), Cardium edule (?), Mytilus, probably two species, Paludina lenta (?), Mactra, Mya, etc. These are the beds which I placed in the horizon of what I have termed the. Westleton shingle, and which in the neighbourhood of Southwold contain casts of Mytili and other shells in abundance, and reposes in all that area on the Chillesford clay.

Joseph Prestwich. 